\title{
Evaluation of Serum Amyloid A Levels in Celiac Disease
}

\section{Çölyak Hastalığında Serum Amiloid A Düzeylerinin Değerlendirilmesi}

\author{
Refika Yorulmaz Çakmak1, (1) Nergiz Ekmen², (1) Mustafa Kavutcu³, (1) Özlem Gülbahar³, (1) Mehmet Arhan² \\ ${ }^{1}$ Mardin State Hospital, Clinic of Internal Medicine, Mardin, Turkey \\ ${ }^{2}$ Gazi University Faculty of Medicine, Department of Gastroenterology, Ankara, Turkey \\ ${ }^{3}$ Gazi University Faculty of Medicine, Department of Biochemistry, Ankara, Turkey
}

\begin{abstract}
Objective: In celiac disease (CD), gluten intake triggers the release of T-cell-derived pro-inflammatory cytokines leading to an increase in the level of serum amyloid A (SAA). To confirm inflammation caused by CD in patients, SAA level is expected to be a better biomarker candidate than $\mathrm{C}$-reactive protein (CRP). This study investigated the relationship between clinical and biochemical variables used in the follow-up of CD patients and SAA levels.

Methods: This study is a cross-sectional observational study which was conducted in patients who presented with a diagnosis of CD in a university hospital between June 1, 2019 and December 1, 2019. Patients were categorized into two groups based on the presence of tissue transglutaminase (tTG) immunoglobulin. Statistical analysis of data was performed by considering the age, gender, duration of the disease, frequency of compliance with a gluten-free diet, body mass index, and some laboratory parameters [vitamin D (VD), tTG IgA-lgG, CRP] taken simultaneously with the SAA levels.
\end{abstract}

Results: A total of 90 patients, 28 (31.1\%) antibody positive and 62 (68.9\%) antibody negative, were included in the study. We found out that there was a statistically significant difference between between SAA level, VD levels, and the duration of CD in the patients ( $p=0.03$ and $\mathrm{p}=0.009$, respectively).

Conclusion: VD levels $<20 \mathrm{ng} / \mathrm{mL}$, in advanced age, and duration of $C D>5$ years should be evaluated in the high-risk groups in terms of high SAA levels. If there is a persistent increase in SAA level during follow-up visits of patients with CD, they should be evaluated in terms of complications caused by the chronic inflammation.

Keywords: Celiac disease, serum amyloid A, C-reactive protein

\section{öz}

Amaç: Çölyak hastalığında (ÇH) gluten alımı, T-hücre kaynaklı pro-enflamatuvar sitokinlerin salınımını tetikleyerek serum amiloid A (SAA) düzeyinde artışa neden olur. Hastalarda ÇH'nin neden olduğu enflamasyonun değerlendirilmesinde, C-reaktif protein (CRP) yerine SAA seviyesi daha iyi bir biyobelirteç olabilir. Bu çalışmada çölyak hastalarının takibinde kullanılan klinik ve biyokimyasal değişkenler ile SAA düzeyleri arasındaki ilişki araştırılmıştır.

Gereç ve Yöntem: Bu çalışma kesitsel gözlemsel bir çalışma olup, 1 Haziran 2019-1 Aralık 2019 tarihleri arasında bir üniversite hastanesinde ÇH tanılı hastalar ile yapılmıştır. Hastalar doku transglutaminaz (tTG) varlığına göre iki gruba ayrıldı. SAA seviyeleri ile yaş, cinsiyet, hastalık süresi, glutensiz diyete uyum sıkığı, vücut kitle indeksine ve eş zamanlı alınan bazı laboratuvar parametreler arasında [D vitamini (VD), tTG IgA-lgG, CRP] istatistiksel analizler yapıldı.

Bulgular: Çalışmaya $28(\% 31,1)$ tTG antikor pozitif ve $62(\% 68,9)$ tTG antikor negatif olmak üzere toplam 90 hasta dahil edildi. Hastalarda VD düzeyleri ve ÇH süresi ile SAA düzeyleri arasında istatistiksel olarak anlamlı bir fark olduğunu saptadık (sırasıyla $p=0,03 ; p=0,009$ ).

Sonuç: $20 \mathrm{ng} / \mathrm{mL}$ 'nin altındaki VD düzeyleri, ileri yaş ve 5 yıldan fazla ÇH süresi bulunan hastalarda SAA yüksekliği açısından riskli gruplar olarak düşünülmelidir. Çölyak hastalarının takiplerinde SAA düzeyinde persiste eden bir yükseklik varsa kronik inflamasyonun neden olduğu komplikasyonlar açısından değerlendirilmelidir.

Anahtar Kelimeler: Çölyak hastalı̆̆ı, serum amiloid A, C-reaktif protein

Address for Correspondence: Nergiz Ekmen, Gazi University Faculty of Medicine, Department of Gastroenterology, Ankara,

Turkey

Phone: +90 5056770557 E-mail: dr_nergisekmen@hotmail.com ORCID ID: orcid.org/0000-0002-7921-3169

Cite as: Yorulmaz Çakmak R, Ekmen N, Kavutcu M, Gülbahar Ö, Arhan M. Evaluation of Serum Amyloid A Levels in Celiac Disease.

Med J Bakirkoy 2021;17:248-253

Received: 28.07.2021

Accepted: 03.09.2021 


\section{INTRODUCTION}

Celiac disease (CD), a chronic immune-mediated enteropathy triggered by dietary gluten ingestion in genetically predisposed individuals, is diagnosed by specific serological and histological factors (1). Highly sensitive and specific antibody tests have been developed and applied to screen individuals with CD (2). Specifically, it is shown that tests for the detection of tissue transglutaminase (tTG) antibody in serum have a specificity of $96-100 \%$ for the diagnosis of $C D$ (1-3). Till date, the only treatment for $C D$ is based on a gluten-free diet, which targets mucosal healing (Marsh 0 or 1 at follow-up biopsy) (4). However, the response to $C D$ treatment with a gluten-free diet is still under debate. If patients were diagnosed with $C D$ in their adolescence or adulthood, approximately $60 \%$ who were on a gluten-free diet in their first year of the treatment achieved mucosal healing (5). In contrast, recent studies indicated that mucosal healing was achieved in $81 \%$ of patients with $C D$ if they were under a long-term, gluten-free follow-up treatment (6).

Serum amyloid A (SAA), produced by hepatocytes, are acute-phase reactants that rise rapidly in infections, trauma, and other inflammatory conditions. It is involved in the pathogenesis of many inflammatory diseases (IDs) such as diabetes mellitus, Alzheimer's disease, rheumatoid arthritis, and ulcerative colitis (7-9). It is shown that high levels of SAA and $\mathrm{C}$-reactive protein (CRP) in biological fluids increases cardiovascular risk, and SAA reached a level which was much higher than CRP and then declined rapidly (10). Increased SAA in patients with rheumatoid arthritis has been associated with disease activity, disease-associated autoantibodies, and other acute-phase reactants (9). Amyloidosis, which is a serious complication in chronic IDs, is formed by the accumulation of amyloid A fibrils, which are degradation products of SAA in certain vital organs (11).

This study aimed to determine the correlation between SAA and various clinical and laboratory parameters in CD patients.

\section{METHODS}

\section{Patients}

This study is a cross-sectional observational study, and the patients who were presented to the University of Health Sciences Turkey, Ankara Keçiören Training and Research Hospital between June 1, 2019 and December 1, 2019 and were diagnosed with CD after the clinical, serological, and histological evaluations, and followed-up, were included in the study. Patients with a serious ID other than CD such as malignancy, active infection, rheumatological and inflammatory bowel disease (IBD), and patients $<18$ years of age were excluded from the study. Written consent was obtained from all patients who participated in the study. Celiac patients were classified as antibody-positive (tTG Ig A or any antibody from tTG IgG positive) and negative (tTG IgA and tTG IgG antibody negative).

\section{Clinical-Demographic Characteristics}

Age, gender, body mass index (BMI), smoking, CD duration, presence of any gastrointestinal symptoms at the time of examination (abdominal pain, diarrhea, constipation, flatulence, dyspepsia, etc.), and dietary compliance were questioned face-to-face by the gastroenterologist.

\section{Laboratory Variables}

Along with the laboratory parameters taken during routine controls of the patients, simultaneous SAA levels were measured [complete blood count, tTG IgA-lgG antibodies, vitamin $D(V D), C R P$, serum iron, ferritin, vitamin B12, folate, alanine aminotransferase (ALT)].

\section{Serum Amyloid A Assay}

Venous blood was collected in a red-capped tube from celiac patients who were admitted to the outpatient clinic with fasting for at least 8 hours. The blood was centrifuged for 10 minutes at 4,000 rpm without waiting. Subsequently, serum was stored at $-80^{\circ} \mathrm{C}$ until the day of analysis. SAA measurements were made for a quantitative determination of SAA (from $\mathrm{mg} / \mathrm{L}$ level) utilizing N-Latex SAA kit immunnefelometer (OQMP11 Germany/Siemens N-Latex SAA Kit, 105 Test Kit). The upper normal limit of SAA is $6.4 \mathrm{mg} / \mathrm{L}$.

\section{Statistical Analysis}

Collected data were analyzed with the SPSS.22 program (Chicago, IL, USA). Descriptive data were presented as the mean \pm standard deviation, median, and minimummaximum values. Chi-square test was used to determine whether there is a relationship between the two variables. When comparing the parameters of more than two patient groups, it was first examined whether the data showed a normal distribution or not with the Kolmogorov-Smirnov tests. For analytical tests, the t-test or Mann-Whitney $U$ test was used to compare the two means. On comparing the three non-parametric analyzed groups, it was tried to be understood between which groups the difference was by performing the dual analyses on data that had a significant difference. Bonferroni correction was made in these analyses. Then, correlation analysis was performed for all parameters in the tTg positive and tTg negative patient group. Non-parametric correlation analysis was used, and $p<0.05$ was considered significant. 


\section{RESULTS}

\section{Demographic Data}

In this study, 90 patients were included, who were subsequently divided into two groups depending on the antibody test results. The mean age of all patients was 36.71 years (Table 1). Summarizes the comparison of clinicallaboratory parameters and SAA levels between the groups according to antibody test results.

\section{Findings on Serum Amyloid A}

Although $75.9 \%$ of patients with high SAA levels were female and only $24.1 \%$ of them were male, there was no statistically significant difference observed between the gender of the patients and SAA groups (high or normal level) ( $p=0.493$ ). The summary of the relation between laboratory variables and SAA levels are presented in Table 2. The results showed that there was a statistically significant difference between SAA levels and the duration of CD, serum CRP level, and age.

More specifically, high SAA level was found in one (10\%) of the patients with a duration of $C D$ for less than one year. High SAA levels were found (mean, $15.25 \mathrm{mg} / \mathrm{L}$ ) in four (15.4\%) of those with durations of CD between 1-5 years, while 24 (44.4\%) of the patients with CD for $>5$ years had a high SAA level (mean, 18.34). Additionally, the results indicated that the duration of $C D>5$ years in $82.8 \%$ of those with a high SAA level, between $1-5$ years in $13.8 \%$, and less than one year in $3.4 \%$, which were statistically significant for comparison between $C D$ duration and SAA groups $(p=0.009)$ (Figure 1).

The CRP level was found high (mean, 11.35) in $31 \%$ of the patients with high SAA levels. In $77.8 \%$ of the patients with high CRP levels, the SAA level was also high. There was a statistically significant relationship observed between

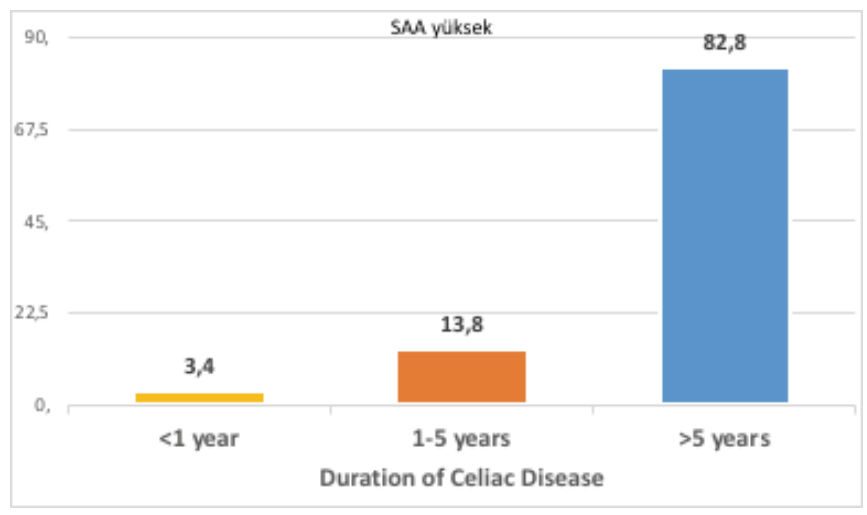

Figure 1. Percentages of higher SAA according to duration of Celiac disease

SAA: Serum Amyloid A
CRP and SAA levels $(p=0.001)$. There was no statistically significant relationship found between SAA groups and generalized finite differencing compliance, BMI, tTG IgA or tTG IgG positivity $(p>0.05)$.

The age was divided into three groups using the k-means cluster method among SPSS analysis programs. SAA levels were found to be higher in 12 of the groups (41.4\%) with a median age of 55.11 (37.9\%) of those with a median age of 37 , and 6 (20.7\%) of those with a median age of 23 years. There was a significant relationship found between the age groups and SAA $(p=0.032)$. When the median age of 23 years and the median age of 55 years were compared with the chi-square method, a statistically significant difference was found in terms of SAA levels $(p=0.009)$.

SAA level was also found to be high when VD levels were examined. VD levels in patients with high SAA levels were $<20 \mathrm{ng} / \mathrm{mL}$ in 16 of patients (42.1\%), between $20-30 \mathrm{ng} / \mathrm{mL}$ in seven of the patients (18.4\%), and $>30 \mathrm{ng} / \mathrm{mL}$ in six of the patients $(54.5 \%)(p=0.03)$. The results showed that the

Table 1. Evaluation of clinical-laboratory parameters according tTG* results

\begin{tabular}{|c|c|c|c|}
\hline Variables & $\begin{array}{l}\text { tTG positive } \\
(n=28)\end{array}$ & $\begin{array}{l}\text { tTG negative } \\
(n=62)\end{array}$ & $p$ \\
\hline Gender (F/M) & $17 / 11$ & $47 / 15$ & 0.1442 \\
\hline $\begin{array}{l}\text { Presence of the } \\
\text { symptoms }\end{array}$ & 14 (50\%) & 20 (32.3\%) & 0.0612 \\
\hline $\begin{array}{l}\text { Not following gluten- } \\
\text { free diet }\end{array}$ & 15 (53.6\%) & $4(6.5 \%)$ & 0.0002 \\
\hline $\begin{array}{l}\text { Adherence to gluten- } \\
\text { free diet }\end{array}$ & $2(7.1 \%)$ & 42 (67.7\%) & 0.0002 \\
\hline Smoking & 17 (60.7\%) & 24 (38.7\%) & 0.052 \\
\hline Anemia $†$ & $6(21.4 \%)$ & $2(3.2 \%)$ & 0.012 \\
\hline $\begin{array}{l}\text { Duration of celiac } \\
\text { disease, years median } \\
\text { Duration of celiac } \\
\text { disease, mean }\end{array}$ & $\begin{array}{l}4(0-19) \\
5.61 \pm 1.01\end{array}$ & $\begin{array}{l}6(0-21) \\
7.95 \pm 0.77\end{array}$ & 0.063 \\
\hline $\begin{array}{l}\text { Alanine } \\
\text { aminotransferase, } \\
\text { median (U/L) }\end{array}$ & $21.5(10-92)$ & $16(7-54)$ & 0.0023 \\
\hline $\begin{array}{l}\text { C-reactive protein, } \\
\text { median (mg/L) }\end{array}$ & $\begin{array}{l}2.05 \\
(0.5-16.9)\end{array}$ & $2.05(0.5-14.1)$ & 0.8343 \\
\hline $\begin{array}{l}\text { Vitamin } D \text {, median } \\
(\mathrm{ng} / \mathrm{mL})\end{array}$ & $19.5(5-114)$ & 21 (6-139) & 0.4613 \\
\hline $\begin{array}{l}\text { Serum Amyloid A } \\
(\mathrm{mg} / \mathrm{L})\end{array}$ & $\begin{array}{l}7.65 \\
(3.69-202)\end{array}$ & $7.22(3.57-17.9)$ & 0.6263 \\
\hline
\end{tabular}

${ }^{1}$ Independent simple t-test, ${ }^{2}$ chi-square test, ${ }^{3}$ Mann-Whitney $U$ test. Values $p<0.05$ are expressed in bold

"tTG: Anti-tissue transglutaminase, †Anemia definition: According to the Turkish hematology society's guideline, hemoglobin limit was accepted as $13 \mathrm{~g} / \mathrm{dL}$ for men, $12 \mathrm{~g} / \mathrm{dL}$ for women, and $11 \mathrm{~g} / \mathrm{dL}$ for pregnant women 
patients with a VD level of $<20 \mathrm{ng} / \mathrm{mL}$ are 3.23 times more likely to have a higher SAA level than those between 20-30 $\mathrm{ng} / \mathrm{mL}$.

As a result of the correlation analysis performed to determine the relationship between SAA and study variables in CD patients, a statistically significant positive correlation was found between the SAA level and CRP ( $r=0.453, p=0.001)$, $\operatorname{ALT}(r=0.314, p=0.026)$ (Table 3).

\section{DISCUSSION}

Table 2. Evaluation of laboratory parameters according to SAA results

\begin{tabular}{|c|c|c|c|}
\hline & $\begin{array}{l}\text { High SAA } \\
(n=28)\end{array}$ & $\begin{array}{l}\text { Normal SAA } \\
(n=61)\end{array}$ & $p$ \\
\hline Age (years) & $40.96 \pm 14.02$ & $34.85 \pm 12.85$ & $0.046^{1}$ \\
\hline $\begin{array}{l}\text { Duration of celiac } \\
\text { disease }\end{array}$ & $8(0.8-21)$ & $4.75(0-21)$ & $0.023^{2}$ \\
\hline $\begin{array}{l}\text { Alanine } \\
\text { aminotransferase } \\
(\mathrm{U} / \mathrm{L})\end{array}$ & $19(8-36)$ & $16(7-92)$ & $0.136^{2}$ \\
\hline B12 (ng/L) & $212.5(81-685)$ & 241 (84-1344) & $0.349^{2}$ \\
\hline $\begin{array}{l}\text { C-reactive protein } \\
(\mathrm{mg} / \mathrm{L})\end{array}$ & $3.55(1.2-14.1)$ & $1.7(0.5-10.4)$ & $0.000^{2}$ \\
\hline Iron ( $\mu \mathrm{g} / \mathrm{dL})$ & $80(28-170)$ & 77.50 (10-235) & $0.404^{2}$ \\
\hline Vitamin D (ng/mL) & $17.5(6-50)$ & $22(5-139)$ & $0.130^{2}$ \\
\hline Ferritin (ng/mL) & $17(7-115)$ & $18(2-93)$ & $0.710^{2}$ \\
\hline Folic acid (ng/mL) & $8(2-13)$ & $8(1-23)$ & $0.625^{2}$ \\
\hline Hemoglobin (g/dL) & $14.39 \pm 1.57$ & $13.95 \pm 1.73$ & $0.262^{1}$ \\
\hline Lymphocyte (mm³/L) & $\begin{array}{l}1965(1160- \\
3640)\end{array}$ & $\begin{array}{l}1910(900- \\
3900)\end{array}$ & $0.354^{2}$ \\
\hline
\end{tabular}

IIndependent simple t-test, ${ }^{2}$ Mann-Whitney $U$ test values $p<0.05$ are expressed in bold, SAA: Serum Amyloid A

For CD patients' follow-up, there is a high need for a noninvasive marker that may be used to show the active inflammation, disease activity, and further complications. T-cell-derived pro-inflammatory cytokines triggered by a gluten intake in CD patients may increase SAA level. Most of the studies mainly focused on the effect of SAA level on acute or chronic IDs. For example, SAA was compared with other acute-phase reactants such as CRP, and the SAA level was found to be more sensitive than CRP in terms of screening of the inflammation in various diseases, such as rheumatoid arthritis, primary biliary cirrhosis, and chronic active hepatitis $(9,12,13)$. Besides, the SAA levels increase rapidly within a few hours of infection, trauma, cancer, or other inflammatory events (14). Familial Mediterranean fever,

\begin{tabular}{lll}
\hline $\begin{array}{l}\text { Table 3. Correlation results between SAA and study variables } \\
\text { levels }\end{array}$ & $\mathrm{r}$ & $\mathrm{p}$ \\
\hline Variables & 0.053 & 0.718 \\
\hline Age (years) & 0.366 & 0.01 \\
\hline Alanine aminotransferase (U/L) & 0.007 & 0.964 \\
\hline B12 (ng/L) & 0.418 & 0.003 \\
\hline C-reactive protein $(\mathrm{mg} / \mathrm{L})$ & 0.080 & 0.585 \\
\hline Iron $(\mu \mathrm{g} / \mathrm{dL})$ & -0.177 & 0.223 \\
\hline Vitamin $\mathrm{D}(\mathrm{ng} / \mathrm{mL})$ & 0.251 & 0.082 \\
\hline Ferritin $(\mathrm{ng} / \mathrm{mL})$ & -0.027 & 0.856 \\
\hline Folic acid $(\mathrm{ng} / \mathrm{mL})$ & 0.229 & 0.113 \\
\hline Hemoglobin $(\mathrm{g} / \mathrm{dL})$ & -0.003 & 0.983 \\
\hline Lymphocyte $(\mathrm{mm} / \mathrm{L})$ & \\
\hline Values $\mathrm{p}<0.05 \mathrm{are} \mathrm{expressed} \mathrm{in} \mathrm{bold,} \mathrm{SAA:} \mathrm{Serum} \mathrm{Amyloid} \mathrm{A}$ & \\
\hline
\end{tabular}

chronic respiratory diseases, Hashimoto's disease, and IBDs have been also associated with the increased SAA levels $(8,15-19)$. CD may present with a variety of extraintestinal manifestations (20). Other studies showed the increase in acute and chronic kidney diseases in CD patients who need renal replacement therapy $(21,22)$. However, to the best of our knowledge, there is no information regarding the relation between SAA level and CD in the literature.

In addition, it is observed that VD deficiency causes inflammation. In our study, we found a relationship between low VD levels and high SAA levels. Many studies on VD and some markers of inflammation are available. For example, VD replacement has been shown to reduce the CRP levels in a meta-analysis (23). The effect of VD level on IL-10, IL-6, and tumor necrosis factor - $\alpha$ levels were also examined (24). Although there is no study showing the relation of the SAA level with VD in the literature, there is a study focusing on the relation of VD with serum amyloid $p$ level in the Arabian race, the results of which indicated that serum amyloid $p$ levels decreased with the replacement of VD (25).

Various cardiac pathologies occur as inflammatory mediators cause atherosclerosis and vascular damage due to their increase by the result of the autoimmune mechanisms triggered in CD (10). It has been shown that high SAA and CRP levels are associated with increased cardiovascular risk (26). In AA amyloidosis, amyloid burden and circulating concentration of SAA was $>10 \mathrm{mg} / \mathrm{L}$, and subsequently, a significant decrease in survival of the patients with persistent inflammatory activity was found. During the patients' followup, most of the patients with SAA level consistently $>50$ $\mathrm{mg} / \mathrm{L}$ have showed an increase of amyloid burden and a deterioration of the organ function (27). Moreover, in some 
studies, CD has been connected with both primary and secondary isolated cases of cutaneous amyloidosis (28). Together, there has also been a case report emphasizing the connection between $C D$ and renal amyloidosis with systemic secondary amyloidosis (28). In our study, we found a positive correlation between SAA and CRP as an important inflammation marker. We found a hypothesis that SAA may be an alternative and more sensitive marker compared to CRP to show inflammation, which has not been considered before in the literature. Larger series should be evaluated to reach more precise results.

In this study, we determined the relationship between SAA level and the duration of CD. SAA levels were found to be significantly higher in patients with a duration of $C D>5$ years, regardless of the current antibody of the disease. Patients with CD should be followed-up in terms of SAA level, and those with persistent inflammatory activity should be further tracked to monitor complications caused by chronic inflammation.

\section{Study Limitations}

This study could not include endoscopically evaluated patients with SAA due to the lack of mucosal damage for the comparison. At the time of diagnosis, the patients were seronegative $C D$, and thus, the initial antibody levels of patients could not be reached.

\section{CONCLUSION}

In this study, SAA level might have been a more sensitive marker candidate than the CRP level to show inflammation in patients with $C D$. Groups at a risk for chronic inflammation (VD level $<20 \mathrm{ng} / \mathrm{mL}$, advanced age, CD duration $>5$ years) should be carefully evaluated. More comprehensive studies on SAA level should be conducted.

\section{ETHICS}

Ethics Committee Approval: The study were approved by the University of Health Sciences Turkey, Ankara Keçiören Training and Research Hospital of Local Ethics Committee (no: 2012-KAEK-15/1895, date: 08.05.2019).

Informed Consent: Written consent was obtained from patients who participated in the study.

\section{Authorship Contributions}

Surgical and Medical Practices: R.Y.Ç., M.A., N.E., Concept: R.Y.Ç., M.A., M.K., Ö.G., N.E., Design: R.Y.Ç., M.A., M.K., Ö.G., N.E., Data Collection or Processing: R.Y.Ç., M.A., M.K., Ö.G., N.E., Analysis or Interpretation: R.Y.Ç., M.A., M.K., Ö.G., N.E., Literature Search: R.Y.Ç., M.A., M.K., Ö.G., N.E., Writing: R.Y.Ç., M.A., N.E.
Conflict of Interest: No conflict of interest was declared by the authors.

Financial Disclosure: The authors declared that this study received no financial support.

\section{REFERENCES}

1. McCarty TR, O'Brien CR, Gremida A, Ling C, Rustagi T. Efficacy of duodenal bulb biopsy for diagnosis of celiac disease: a systematic review and meta-analysis. Endosc Int Open 2018;6:E1369-78.

2. Al-Toma A, Volta U, Auricchio R, Castillejo G, Sanders DS, Cellier C, et al. European Society for the Study of Coeliac Disease (ESsCD) guideline for coeliac disease and other gluten-related disorders. United European Gastroenterol J 2019;7:583-613.

3. Lewis NR, Scott BB. Meta-analysis: deamidated gliadin peptide antibody and tissue transglutaminase antibody compared as screening tests for coeliac disease. Aliment Pharmacol Ther 2010;31:73-81.

4. Rubio-Tapia A, Ludvigsson JF, Brantner TL, Murray JA, Everhart JE. The prevalence of celiac disease in the United States. Am J Gastroenterol 2012;107:1538-44.

5. Sharkey LM, Corbett G, Currie E, Lee J, Sweeney N, Woodward $J M$. Optimising delivery of care in coeliac disease - comparison of the benefits of repeat biopsy and serological follow-up. Aliment Pharmacol Ther 2013;38:1278-91.

6. Hære P, Høie O, Schulz T, Schönhardt I, Raki M, Lundin KE. Longterm mucosal recovery and healing in celiac disease is the rule - not the exception. Scand J Gastroenterol 2016;51:1439-46.

7. Liang JS, Sloane JA, Wells JM, Abraham CR, Fine RE, Sipe JD. Evidence for local production of acute phase response apolipoprotein serum amyloid A in Alzheimer's disease brain. Neurosci Lett 1997;225:73-6.

8. Vietri L, Fui A, Bergantini L, d'Alessandro M, Cameli P, Sestini P, et al. Serum amyloid A: A potential biomarker of lung disorders. Respir Investig 2020;58:21-7.

9. Kumon Y, Suehiro T, Hashimoto K, Nakatani K, Sipe JD. Local expression of acute phase serum amyloid A mRNA in rheumatoid arthritis synovial tissue and cells. J Rheumatol 1999;26:785-90.

10. Shridas $P$, Tannock LR. Role of serum amyloid $A$ in atherosclerosis. Curr Opin Lipidol 2019;30:320-5.

11. Ertürk A, Korkmaz C. AA Amiloidozda Patogenez. Turkiye Klinikleri J Rheumatol-Special Topics 2017;10:163-6.

12. Chambers RE, MacFarlane DG, Whicher JT, Dieppe PA. Serum amyloid-A protein concentration in rheumatoid arthritis and its role in monitoring disease activity. Ann Rheum Dis 1983;42:665-7.

13. Raynes JG, Cooper EH. Comparison of serum amyloid A protein and $\mathrm{C}$-reactive protein concentrations in cancer and non-malignant disease. J Clin Pathol 1983;36:798-803.

14. De Buck M, Gouwy M, Wang JM, Van Snick J, Proost P, Struyf S, et al. The cytokine-serum amyloid A-chemokine network. Cytokine Growth Factor Rev 2016;30:55-69.

15. Erden S, Buyukozturk S, Vural P, Değirmencioğlu S. Acutephase reactans in Hashimoto thyroiditis. Int Immunopharmacol 2008:8:1863-5.

16. Dai ML, Fan S, Li Z, Yu X, Lin D, Huang XF, et al. Correlation of serum amyloid $A$ levels, clinical manifestations, treatment, and disease activity in patients with acute anterior uveitis. Eye (Lond) 2020;34:1672-8.

17. El-Deeb W, Elsohaby I, Fayez M, Mkrtchyan HV, El-Etriby D, ElGioushy M. Use of procalcitonin, neopterin, haptoglobin, serum amyloid $\mathrm{A}$ and proinflammatory cytokines in diagnosis and 
prognosis of bovine respiratory disease in feedlot calves under field conditions. Acta Trop 2020;204:105336.

18. Yuan $Z Y$, Zhang $X X, W u$ YJ, Zeng ZP, She WM, Chen SY, et al. Serum amyloid A levels in patients with liver diseases. World $J$ Gastroenterol 2019;25:6440-50.

19. Bourgonje AR, von Martels JZH, Gabriëls RY, Blokzijl T, BuistHoman M, Heegsma J, et al. A Combined Set of Four Serum Inflammatory Biomarkers Reliably Predicts Endoscopic Disease Activity in Inflammatory Bowel Disease. Front Med (Lausanne) 2019;6:251.

20. Frustaci A, Cuoco L, Chimenti C, Pieroni M, Fioravanti G, Gentiloni $\mathrm{N}$, et al. Celiac disease associated with autoimmune myocarditis. Circulation 2002; 105:2611-8.

21. Wijarnpreecha K, Thongprayoon C, Panjawatanan P, Thamcharoen N, Pachariyanon P, Nakkala K, et al. Celiac disease and the risk of kidney diseases: A systematic review and meta-analysis. Dig Liver Dis 2016;48:1418-24.

22. Ludvigsson JF, Montgomery SM, Olén O, Ekbom A, Ludvigsson J, Fored M. Coeliac disease and risk of renal disease-a general population cohort study. Nephrol Dial Transplant 2006;21:1809-15.

23. Chen N, Wan Z, Han SF, Li BY, Zhang ZL, Qin LQ. Effect of vitamin D supplementation on the level of circulating high-sensitivity
C-reactive protein: a meta-analysis of randomized controlled trials. Nutrients 2014;6:2206-16.

24. Calton EK, Keane KN, Soares MJ. The potential regulatory role of vitamin D in the bioenergetics of inflammation. Curr Opin Clin Nutr Metab Care 2015;18:367-73

25. Amer OE, Khattak MNK, Alnaami AM, Aljohani NJ, Al-Daghri NM. Vitamin D Correction Down-Regulates Serum Amyloid P Component Levels in Vitamin D Deficient Arab Adults: A SingleArm Trial. Nutrients 2020;12:2880.

26. Ridker PM, Rifai N, Pfeffer MA, Sacks FM, Moye LA, Goldman S, et al. Inflammation, pravastatin, and the risk of coronary events after myocardial infarction in patients with average cholesterol levels. Cholesterol and Recurrent Events (CARE) Investigators. Circulation 1998;98:839-44.

27. Gillmore JD, Lovat LB, Persey MR, Pepys MB, Hawkins PN. Amyloid load and clinical outcome in AA amyloidosis in relation to circulating concentration of serum amyloid A protein. Lancet 2001;358:24-9.

28. Chhoda A, Jain D, Kumar Daga M, Batra V. Celiac Disease and Secondary Amyloidosis: A Possible Causal Association? ACG Case Rep J 2018;5:24. 